\title{
How Is the Thinking Process of Students in Solving Math Problems Based on the Adversity Quotient in High School?
}

\author{
Luthfi Nur Pamungkas ${ }^{1, *}$ Tri Atmojo Kusmayadi ${ }^{2}$ Laila Fitriana $^{3}$ \\ ${ }^{1}$ Postgraduate Program of Mathematics Education Universitas Sebelas Maret, Surakarta, Indonesia \\ ${ }^{2}$ Faculty of mathematics and Natural Sciences Universitas Sebelas Maret, Surakarta, Indonesia \\ ${ }^{3}$ Faculty of Teacher Training and Education Universitas Sebelas Maret, Surakarta, Indonesia \\ *Corresponding author. Email: luthfinurpamungkas@studets.uns.ac.id
}

\begin{abstract}
Mathematics is always related to simple problems to complex problems. The problems given affect the thinking process of students. The problem-solving process also requires hard work to overcome the existing difficulties or what is called the adversity quotient. This study aims to determine the thought processes of climber and quitter in solving math problems. This research is qualitative research, with research subjects consisting of nine students from class eleven in senior high school. Subject selection using purposive sampling. The research subjects were selected based on the results of the Adversity Quotient questionnaire. The data collection method in this research is by observation, test, and interview method. Data validation was carried out by method triangulation. The data analysis technique used in this research according to Miles and Huberman, namely data reduction, data presentation, and drawing conclusions or verification. The results showed that the thinking process in solving the problems of the climber and quitter students met the indicators of the predicative thinking process.
\end{abstract}

Keywords: Thinking Process, Climber, Quitter, Solving Math Problem, Adversity Quotient.

\section{INTRODUCTION}

Mathematics is one of the subjects at every level of education. Mathematics is a tool/means to overcome the problems that exist in life [1]. mathematical objectives listed in the 2013 curriculum, namely so that students are able to develop the abilities they already have to be able to solve a problem. Mathematics learning has been conveyed to students in an informative manner [2]. This means that only information from the teacher is obtained by students. With this kind of learning, students are less involved in finding the learning concepts that must be mastered. The concepts given do not leave a sharp mark in memory so that students easily forget and are often confused in solving a different problem. Students learn mathematics only by imitating and recording problem solving from the teacher[3], while learning mathematics does not involve students in active learning, emphasizes less on student understanding, and students only accept teacher explanations[4].
This shows that students' ability to solve problems in the circular equation material is also still low. One of the reasons is because the questions tend to be monotonous and less varied. Students think more about how to work if the questions are varied, the ability to solve problems and think can be improved. Using complex problems, it can improve thinking processes because students have to do more thinking processes to be able to solve problems [5]. The questions given are not only those that require memorizing formulas. However, the questions given are questions that require a higher understanding and thought process. The level of the questions given is also gradual, starting from simple, medium to difficult or using at least two steps of

A person's problem-solving ability can be increased by providing several levels of problems [6]. Routine and non-routine problem solving tends to have a positive effect on problem solving [7]. Solving mathematical problems in learning is very important because it can determine mathematical abilities with new knowledge and reflect on the problem solving 
process [8]. One of the troubleshooting steps used is the Santrock step. The steps for solving Santrock are: 1) finding and compiling problems. 2) develop problem solving strategies. 3 ) evaluate solutions, and 4) think about and redefine problems and solutions [9].

The thinking process of students in problem solving is different from one student to another. The thinking process is a process consisting of receiving information (from within or from outside the student), processing, storing, and recalling the information from the student's memory [10]. It can be seen that the thinking process is a process that starts from receiving information, processing, and concluding in solving problems. The thinking process is divided into two types, namely the type of predicative thinking and the type of functional thinking. The predicative thinking type is a way of thinking with a tendency to see the relationship between two or more concepts in making decisions, while the functional thinking type is a way of thinking with more emphasis on seeing links and how to implement decisions [10].

If the questions that contain problems from the teacher are done by students, the students' thinking tends to be the same as the example questions given by the teacher. However, if students are given questions that are slightly different from the examples given, students will find it difficult to work on the questions. Differences in problems result in not being able to solve problems with the knowledge they have [11]. New problems require new ideas to solve them [11]. So, students do not only know and memorize the steps given by the teacher. So, students do not only know and memorize the steps given by the teacher.

Efforts to overcome existing difficulties are also required in the problem-solving process. Adversity Quotient (AQ) is an intelligence or ability to change, process a problem or difficulty and make it a challenge to be solved [12]. It can be seen that AQ is the ability to turn a difficulty into a challenge. [12] classified a person's AQ into 3 namely climber, camper and quitter. Climbers are a group of people who choose to continue to struggle in the face of various kinds of things that will continue to hit both in the form of problems, challenges, obstacles, and other things that continue to be obtained every day. Campers are a group of people who already have the will to try to face the problems and challenges that exist, but they stop because they feel they can't anymore. While quitters are a group of people who lack the will to accept challenges in their lives.

Based on research conducted, there is a significant relationship between AQ and academic achievement of St. Joseph Quezon City for the 2008-2009 school year [13]. there is a comparison between students who have high rather than medium and low mathematical abilities by using simple questions because complex questions have not been used. The higher the level of education, the more complex the level of difficulty of math problems [14]. Processes can be improved by using complex problems [5]. This can be seen from the way students solve geometry problems which require describing the problem first. Students must do more thinking processes to be able to solve problems. It can be concluded that $\mathrm{AQ}$ has a relationship with academic achievement which can be seen from the differences in students' thinking processes in solving problems.

So based on this explanation, this study aims to determine students' thinking processes in solving math problems based on the adversity quotient in high school.

\section{RESEARCH METHOD}

The method used in this research is descriptive qualitative. Qualitative research is research that is intended to understand the phenomenon of what is experienced by research subjects such as behavior, perception, motivation, action, and others, holistically, and by way of description in the form of words and phrases. language, in a special natural context and by utilizing various natural methods [15]. This type of research analyzes students' thinking processes in solving circle problems.

The research was carried out in the eleventh grade of the third state high school which is one of the leading schools in Boyolali for the 2019/2020 school year. Subject selection was carried out using purposive sampling technique. Purposive sampling is a selective sampling technique using certain considerations held [16]. The considerations in the selection of subjects are based on considerations, namely 1. Class eleven who have studied the circle material because the problem is related to the circle material so that it is expected to be able to solve problems, 2. Able to communicate well in order to provide sufficient information or in accordance with the research objectives, and 3. meet the adversity quotient criteria. Furthermore, interviewing subject teachers to ask for consideration of subjects that match the criteria so that subjects who meet the criteria are obtained. The instruments used in this study are the main instrument and the auxiliary instrument. The main research is the researcher himself, while the auxiliary research instruments are adversity quotient questionnaires, problem solving tests, and interview guidelines. 
The data obtained were validated by triangulation. Triangulation is a technique of checking the validity of data that utilizes something else [15]. The triangulation technique used is the triangulation method. Triangulation method was used to compare the results of the analysis of student work with the results of interviews with students who were selected as subjects. After the triangulation process, it was seen that there was continuity between the results of the student work analysis and the results of the interviews.

The problem given, there are two pipes that will be tied with a rope in a certain position. The first pipe has a cross-sectional equation The second pipe has a radius of 1.8 times the first. If the centre of the cross section of the first pipe has the same abscissa as the equation of the cross section of the second pipe, determine the cross-sectional equation of the second pipe.

\section{RESULT AND DISCUSSION}

The results of this study were to determine the students' thinking processes in solving problems related to the circle material. Based on students' answers, researchers can find out how students' thinking processes in solving problems

\subsection{Subject Climber (CL)}

The following are the results of the climber subject's written test in solving problems, which are presented in

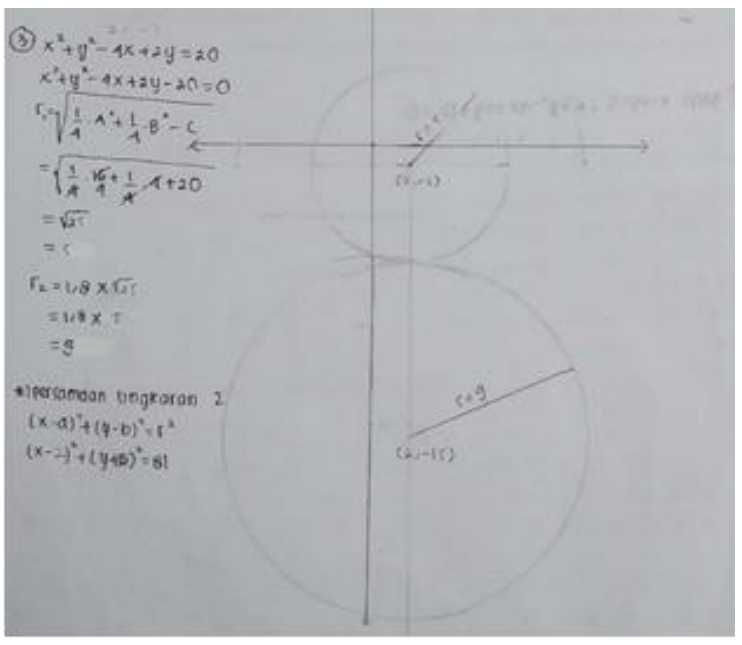

Figure 1 The results of the CL written test

\subsubsection{Finding and compiling problems}

To find out what climber subjects did in the steps of finding and compiling problems below, we have excerpts from interviews that have been conducted with climber subjects.

Q : What do you understand from this question?

CL : From question number 3, it is known that there are two pipes that are tied in a certain position. Pipe 1 is known for its cross-sectional equation, while pipe 2 is only known for the length of the radius 1.8 times the cross section 1. The centre of the cross section of pipe 1 and pipe 2 has the same abscissa.

Q : What is being asked in this question?

CL : From question number 3 I was asked to find the equation of the cross section of pipe 2.

Q : What is known and what is being asked can solve the problem?

CL : Yes ma'am.

Based on the results of the written test in Figure 1 and the interview excerpts, it can be concluded that the subject of CL was able to express in his own words what was known and asked in the question. CL subjects also understand the information that is already available to solve the problem.

\subsubsection{Develop a Problem-Solving Strategy}

To find out what CL subjects did in the step of developing problem-solving strategies, the following excerpts from interviews that have been conducted with CL subjects.

Q : What strategy did you use to solve the problem?

CL : First I find the radius of the crosssectional equation of pipe 1. After that, I find the radius of the equation of the cross-section of the second pipe by multiplying the first radius by 1.8. The second I draw the equation of the cross section of pipe 1. Because the cross sections of pipes 1 and 2 have the same abscissa, then I draw pp. The center of the equation of the cross-section of pipe 1 is straight down so that from the edge of the circle to the center of the equation of the cross-section of pipe 2. So the distance between the center of the equation of the cross-section of pipe 2 and the edge of circle 1 is 9. From that, I can find out the center of the equation of the cross-section of pipe 1 and pipe 2 To find the equation, I plugged the circle's 
center and radius into the general equation of the circle.

Q : Are you sure about the strategy you are using?

CL : I believe in the method I use.

Based on the results of the written test in Figure 1 and interview quotes, it can be concluded that CL subjects can find out what strategies are used to solve problems. CL subjects can know in detail the strategy to be used and believe in it.

\subsubsection{Evaluating Solutions}

To find out what CL subjects did in the step of evaluating solutions below, we have excerpts from interviews that have been conducted with AR subjects.

Q : Let me describe the strategy you use how do you get the radius of circle 1 ?

$\mathrm{CL}$ : To get the radius of the circle 1 I use the formula.

Q : How did you get the center of the first circle?

CL : The center of the circle 1 is obtained from the formula for the center of the circle, namely.

Based on the results of the written test in Figure 1 and interview quotes, it can be concluded that CL subjects are able to solve problems coherently according to the chosen strategy.

\subsubsection{Rethink and modify problems and solutions}

To find out what CL subjects did at the step of thinking and modifying the problems and solutions below, we have excerpts from interviews that have been conducted with CL subjects.

Q : Are you sure about all the work you do?

CL : Actually, I'm not sure because it's the first time I've worked on a problem like this. But the information that is known is quite helpful in solving the problem.

Q : Is there any other way to do this problem?

CL : Sorry, I only understand that way.

Based on the results of the written test in Figure 1 and the interview excerpt, it can be concluded that the CL subject doubted the truth of the answer because it was the first time working on such a question and did not understand other ways to solve the problem.

\subsection{Subject Quitter $(Q U)$}

The following are the results of the QU subject's written test in solving the first problem, which is presented in Figure 2

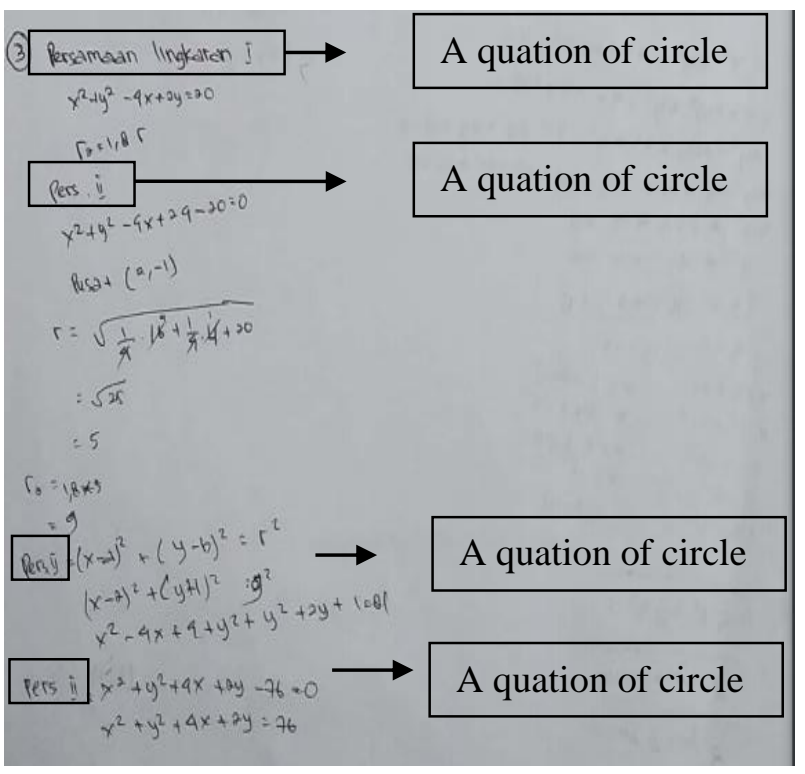

Figure 2 The results of the QU written test

\subsubsection{Finding and compiling problems}

To find out what the QU subject did in the steps of finding and compiling the problem, the following excerpts from interviews that have been conducted with the QU subject.

Q : For this question, Read the question first.

QU : Yes.

Q : What is asked in the question?

QU : From question number 3 I was asked to find the equation of the cross section of pipe 2.

Q : What do you know about this question?

QU : From question number 3, it is known that there are two pipes that are tied in a certain position. Pipe 1 is known for its cross-sectional equation, while pipe 2 is only known for the length of the radius 1.8 times the cross section 1. The center of the cross section of pipe 1 and pipe 2 has the same abscissa.

Q : What do you understand from this question?

QU : In the problem, it is known that two pipes are tied in a certain position. Pipe 1 is known for its cross-sectional equation, while pipe 2 is only known to have a radius of 1.8 times its cross-section. The 
center of the cross-section of pipe 1 and pipe 2 have the same abscissa and I was asked to find the equation of the cross section of pipe 2 .

Q : Is there any other information needed to do this question?

QU : No.

Q : Why?

QU : Because question is clear enough that I was asked to find the equation for the cross section of pipe 2.

Based on the results of the written test in Figure 2 and interview excerpts, it can be concluded that the MS subject is able to express in his own words what is known and asked in the question. QU subjects also stated that they understood the problems given.

\subsubsection{Developing a Problem-Solving Strategy}

To find out what QU subjects did in the step of developing problem-solving strategies, the following excerpts from interviews that have been conducted with QU subjects.

Q : What strategy did you use to answer this question?

QU : First I find the center of the circle from equation 1. the radius of the equation of the cross-section of the pipe 1. After that, I find the radius of the equation of the cross-section of the second pipe by multiplying the first radius by 1.8. From that, I can find out that the center of the equation for the cross section of pipe 2 is equal to section 1 and the radius of section 2. To find out the equation, I enter the center of the circle and the radius into the general equation of the circle.

Q : Are you sure about the strategy you are using?

QU : I believe in the method I use.

Based on the results of the written test in Figure 2 and interview excerpts, it can be seen that QU subjects tend to be to the point in solving problems so that they do not relate the materials/concepts/formulas that have been studied and know what strategies to use but are not appropriate. QU subjects only know the strategy used. However, they do not know that there are deficiencies in the strategy used.

\subsubsection{Evaluating Solutions}

To find out what MS subjects did in the step of evaluating solutions below, we have excerpts from interviews that have been conducted with MS subjects.

Q : How do you find the center of a circle?

QU : By using the formula.

Q : After getting the center of the circle what do you do?

QU : Finding the radius of the pipe cross section 1 .

Q : How do you find the cross-sectional radius of pipe 1 ?

QU : By using the formula

Q : After that what do you do?

QU : Find the radius of the second pipe crosssection by multiplying the first radius by 1.8 .

Q : Then what do you do?

QU : After that calculate the equation of the second pipe cross section.

Based on the results of the written test in Figure 2 and interview excerpts, it can be concluded that the QU subject uses the steps used, namely the steps that are not coherent. This happens because the QU subject assumes that the center of the first pipe with the second pipe is the same.

\subsubsection{Rethinking and modify problems and solutions}

To find out what QU subjects did at the step of thinking about and modifying the problems and solutions below, we have excerpts from interviews that have been conducted with QU subjects.

Q : Are you sure about the solution you are working on?

QU : I'm sure.

Q : Why?

QU : Because I've worked on questions similar to the questions you gave.

Q : Is there a solution other than the one you used?

QU : I don't know.

Based on the results of the written test in Figure 2 and the interview excerpt, it can be concluded that the QU subject believed in the truth of the answer because according to the subject QU had worked on questions similar to the questions given. QU subjects believed that the answer was correct because they did not know that the answer was wrong. 
Based on the results of the research description, it can be seen that the thinking process in solving the problem of climber students meets the indicators of the predicative thinking process. The first indicator is that students are able to express what is known and asked and determine whether what is known and asked is sufficient to solve the problem. Students mention the information contained in the questions and also mention what things are known or asked[17]. Students can find out information from problems using their own language[18]. The second indicator is that students are able to relate the material / concepts / formulas that exist in the problem with material that has been studied correctly and are able to know what strategies will be used correctly. This is in accordance [17] which relates to the knowledge that has been possessed and also mentions what is done or used to solve problems and also prepares plans or steps for solving problems. Students can plan problem solving according to their knowledge[18]. The third indicator is that students are able to solve problems using coherent steps. This is in accordance [17], namely carrying out a problem-solving plan. The subject applied the plan according to the knowledge he had[17]. The fourth indicator is that students believe in the truth of the problem solution but have not been able to find another solution method. This is in accordance [17], namely believing in the truth of problem solving. As revealed in the research of [19] that self-confidence can foster motivation to be able to solve mathematical problems.

The thinking process in solving the problem of quitter students fulfills the functional thinking process indicators. The first indicator is that students are unable to express what is known and asked because they tend to want to quickly solve problems. This is in accordance with [17], which is to mention the information contained in the questions even though the language is not good. The opinion of [18] also states that students cannot find out information immediately from problems using their own language. The second indicator is that students are not able to relate the material/concepts/formulas that exist in the problem with material that has been studied correctly and are unable to know what strategies will be used correctly because they tend to be to the point. This can be seen from not being able to relate the material / concepts / formulas that have been studied and not being able to know what strategies will be used properly. This is in accordance with [17], namely students are not sure about the decisions taken related to concepts related to the problem so they do not mention what will be done to solve the problem. The third indicator is that students are not able to solve problems in a coherent way. This can be seen because the subject has not been able to solve the problem using coherent steps, resulting in an error in solving it. This is in accordance with [17], namely not carrying out the problemsolving plan. The fourth indicator is that students doubt the correctness of the problem solution and do not use other solutions. This is in accordance with [17], which is not sure about the results of the problem solving he obtained.

\section{CONCLUSION}

Based on the results of the research and discussion, the following conclusions are obtained when the thinking process in solving the problem of climber students fulfils the indicators of the predicative thinking process. The first indicator is that students are able to express what is known and asked and determine whether what is known and asked is sufficient to solve the problem. The second indicator is that students are able to relate the material/concepts/ formulas that exist in the problem with material that has been studied correctly and are able to know what strategies will be used correctly. The third indicator is that students are able to solve problems using coherent steps. The fourth indicator is that students believe in the truth of the problem solution but have not been able to find another method of solving it.

The thinking process in solving the problem of quitter students fulfils the functional thinking process indicators. The first indicator is that students are unable to express what is known and asked because they tend to want to quickly solve problems. The second indicator is that students are not able to relate the material/concepts/formulas that exist in the problem with material that has been studied correctly and are unable to know what strategies will be used correctly because they tend to be to the point. The third indicator is that students are not able to solve problems in a coherent way. The fourth indicator is that students doubt the correctness of the problem solution and do not use other solutions.

\section{ACKNOWLEDGMENTS}

The authors thank the Senior High School Three wich includes excellent schools in Boyolali for giving the opportunity to do retrieval research data.

\section{REFERENCES}

[1] Suyitno, H. Hubungan Antara Bahasa dengan Logika \& Matematika Menurut Pemikiran Wittgenstein. Jurnal Humaniora 20 (1) 26-37. Surabaya: UNAIR 2008.

[2] Turrmudi. Landasan Filsafat \& Teori Pembelajaran Matematika (Berparadigma 
Eksploratif \& Investigatif). Jakarta: Leuser Cipta Pustaka. 2008.

[3] Mettes, C.T.W. Teaching and Learning Problem Solving in Science A General strategy. International Journal of Science Education, 57 (3), $882-885.1979$.

[4] Slettenhaar. Adapting Realistic Mathematics Education in the Indonesian Context. Prosiding Konperensi Naional Matematika X ITB, 17-20 Juli 2000. 2000

[5] Graves, B. The Corponal Turn in Mathematical Thinking. Prosidia Sosial and Behavior Sciences, hlm: 1358-1361. Elsavier. 2014.

[6] Webb, N.L. Content complexity and depth-ofknowledge as applicable to research and practice. In D. Mogari; A. Mji; F. Mundalamo \& U.I. Ogbonnaya (eds). Proceedings of ISTE2010 International Conference: Towards Effective Teaching and Meaningful Learning in MST, pp. $1-19.2010$.

[7] Arslan, C. \& Altun, M. Learning to solve nonroutine mathematical problems. Elementary Education Online 6(1), 50-66. 2007.

[8] Sari, D. P., Usodo, B., \& Subanti, S. Metacognitive experience of mathematics education students in open start problem solving based on intrapersonal intelligence. IOP Conf. Series: Journal of Physics: Conf. Series 1008 (2018) 012062. 2018.

[9] Santrock, J. W. Psikologi Pendidikan. Jakarta: Salemba Humanika. 2011.

[10] Marpaung, Y \& Suparno, P. Sumbangan Pikiran terhadap Pendidikan Matematika dan Fisika. Yogyakarta: MIPA IKIP Sanata Dharma. 1987.

[11] Kantowski, M. G. Processes Involved in Mathematical Problem Solving. Journal for Research in Mathematics Education, 8(3), 163180. 1997.

[12] Stoltz, P. G. Adversity Quotient at Work: Make Everyday Challenges the Key to Your SuccessPutting the Principles of AQ Into Action. Canada: John Willey and Sons, Inc. Wiley Publishers. 2000 .

[13] Zhou, H. The Adversity Quotient and Academic Performance Among College Students at St. Joseph's College Quezon City. An Undergraduate Thesis. The Faculty of The
Departments of Arts and Sciences St. Joseph College Quezon City. 2009.

[14] Mogari, D \& Chirove, M. Comparing Grades 1012 Mathematics Learners Non Routine Problem Solving. African Journal of Research in Mathematics, Science and Technology Education 13(8): 4523-4551. 2017.

[15] Moleong, L J. Metodologi Penelitian Kualitatif Edisi Revisi. Bandung: Remaja Rosdakarya. 2012.

[16] Budiyono. Pengantar metode Penelitian. Surakarta: UNS.2017.

[17] Hanafiah, A., Riyadi, \& Sujadi, I. Proses Berpikir Siswa Kelas VII SMP Negeri 2 Semen Kediri Berdasarkan Tahap Proses Berpikir Solso dalam Memecahkan Masalah Matematika Ditinjau dari Adversity Quotient (AQ). JMEE, VI (2), 156166. 2016.

[18] Sari, C. K., Sutopo, \& Aryuna, D. R. The Profile of Students' Thinking in Solving Mathematics Problems Based on Adversity Quotient. Journal of Research and Advances in Mathematics Education, 1 (1) 36-48. 2016.

[19] Callejo, M. L., \& Vila, A. Approach to Mathematical Problem Solving and Students' Belief System: Two Case Studies. Journal of Educational Studies in Mathematics. 72, 111126. 2009. [1] E.M. Clarke, E.A. Emerson, Design and synthesis of synchronization skeletons using branching time temporal logic, in: D. Kozen (Eds.), Workshop on Logics of Programs, Lecture Notes in Computer Science, vol. 131, Springer, Berlin, Heidelberg, 1981, pp. 52-71. DOI: https://doi.org/10.1007/BFb0025774 